\title{
Latin American Thinking in International Relations Reloaded
}

Florent Frasson-Quenoz ${ }^{* \dagger}$

\section{ABSTRACT}

In the midst of uncertainty -generated by the narratives of the decline of the United States-academics are looking for answers and cerebral stimulus in the heart of the academic Terra Incognita that is the "Global South". Building on this interpretation, I formulate a simple question: Does a Latin American school of thought exist in International Relations? In order to respond to this question I will propose a model that will allow for an assessment of the existence of a Latin American school of thought in International Relations. Additionally, this model will enable me to distance myself from the air du temps; that is, to celebrate the existence of a school of thought before even being certain that it actually exists. For sure, the assessment done here will only stand as a first attempt, and is in no way exhaustive. Nonetheless, it will allow me, firstly, to demonstrate that the eagerness to promote any kind of academic proposal to the status of "school" is detrimental to the central goal of generating knowledge and, second, to stimulate others to think about the subject along the same lines.

Key words: Latin american thinking in international relations, research enterprise, knowledge aggregation, global south, autonomy.

* PhD International Security and Defense. Researcher at the Centro de Investigaciones y Proyectos Especiales (CIPE). School of Finances, Government and International Relations. Externado de Colombia University, Bogotá (Colombia).florent.frasson@uexternado.edu.co

$\dagger$ I would like to thank Arlene Tickner and all oAsis members for their valuable comments on early drafts. The views expressed in this article are those of the autor.

Recibido: 29 de febrero de 2016 / Modificado: 15 de marzo de 2016 / Aceptado: 17 de abril de 2016 Para citar este artículo

Frasson-Quenoz, F. (2016). Latin American Thinking in International Relations Reloaded. oAsIs, 23, 53-75. DOI: http://dx.doi.org/10.18601/16577558.n23.04 
Pensamiento

latinoamericano

en relaciones

internacionales recargado

RESUMEN

En medio de la incertidumbre generada por las narrativas de declive de Estados Unidos, los académicos están buscando respuestas y estímulos en el corazón de la Terra Incognita que es el Sur Global. Construyendo sobre esta interpretación, se formula una simple pregunta: ¡ंexiste una escuela de pensamiento latinoamericana en relaciones internacionales? Para responder a ella proponemos, por un lado, un modelo que nos permitirá evaluar la existencia de una Escuela de Pensamiento Latinoamericana. Por otro lado, este modelo nos hará posible alejarnos del air du temps; es decir, celebrar la existencia de una Escuela de Pensamiento antes de estar seguros de que exista. Indudablemente, la evaluación que se hará aquí será solo un primer esbozo, de ninguna manera es exhaustiva. Sin embargo, nos dejará, primero, demostrar que el afán por promover cualquier propuesta al estatus de "Escuela" se hace en detrimento del objetivo central de la generación de conocimiento y, segundo, estimular a otros a pensar este asunto en las mismas líneas.

Palabras clave: pensamiento latinoamericano en relaciones internacionales, esfuerzo investigativo, agregación al conocimiento, sur global, autonomía.

\section{INTRODUCTION}

The way we conceive interactions in world politics has always been a topic of discussion. Nowadays, the reading we do of the international order is a topic of debate not only for academics but also for specialized social networks and, more broadly, in the media. In this particular context, the last economic crisis strengthened those who defend the idea that the international system drifted from unipolarity to "apolarity"; that is to say, that the current state system is under no leadership. Exhausted and discredited, the American superpower is presented as a wanderer without the capacity nor the will to impose its rule. Following this narrative, we are to understand that because no states have the means to overthrow the "hegemon" nor the interest/capacity to fill in the gaps left open in the current world order, leadership is absent (Badie, 2004, 2011).

Obviously, not everyone accepts this sociological reading ${ }^{1}$. Nonetheless, this narrative allows for a contextualization of a much more interesting phenomenon: the increasing attention "non-Western" thinking receives in our discipline (Tickner and Wæver, 2009; Tickner and Blaney 2012). This interest could also be interpreted as a consequence

\footnotetext{
1 However, a wide range of works do postulate the decline of the American power and an even larger number of academics discuss the reconfiguration of the international system's order.
} 
of the "theoretical peace" Dunne, Hansen and Wight described in their 2013 paper (Dunne, Hansen and Wight, 2013: 406): in the midst of uncertainty, academics are looking for answers and cerebral stimulus in the heart of the academic Terra Incognita that is the "Global South".

Building on this interpretation, I formulate a simple question: Does a Latin American school of thought exist in International Relations?

In a period of doubts - generated by the narratives of the decline of the United States - academics from a discipline historically dominated by Anglo-Saxons are more than ever inclined to search meaning and direction in foreign knowledge.

Nothing could better exemplify this context than the speech that Professor Timothy Shaw, director of the Governance-Human Security program at the University of Massachusetts, gave when he commented on Professor Baghat Korany’s 2015 IsA Global South Award - the first Arab scholar to win it $-^{2}$ :

Bahgat Korany's welcome recognition by the ISA Global South Caucus symbolises the increasing limitations of the Us-dominated international relations discipline and the imperative of recognising and welcoming those 'other' perspectives, which are in fact the new mainstream (Geneva's Graduate Institute Alumni News, 2015).

Firstly, this existential search leads me to propose a model that will allow for an assessment of the existence of a Latin American school of thought in International Relations. Secondly, this model will enable me to distance myself from the air du temps; that is, to celebrate the existence of a school of thought even before being certain that it actually exists.

The series of indicators chosen in this paper will allow us to qualify a school of thought as a research enterprise (James, 2002). As is the requisite in science, we do not want to build those indicators ex nibilo. This is why I will follow the analytical sequence proposed by Devlen, James and Özdamar in their 2005 evaluation of the English School (Devlen, James and Özdamar, 2005) and then apply it to the Latin American case ${ }^{3}$. For sure, the assessment done here will only stand as a first attempt, and is in no way exhaustive. Nonetheless, it will allow me, first, to demonstrate that the eagerness to promote any kind of academic proposal to the status of "school" is detrimental to the central goal of generating knowledge and, second, to stimulate others to think about the subject along the same lines.

\footnotetext{
2 "First Arab Scholar to Win Global South Award", is the title the Alumni News of the Geneva's Graduate Institute chose to describe the event. To enter the polemic about the "southern" nature of the academics that receive the distinction one can consult Professor Korany's biography on the Université de Montréal's page: http://pol.umontreal. $\mathrm{ca} /$ repertoire-departement/vue/korany-bahgat/)

3 Here I will only note that the three authors encouraged their lectors to use their analytical tool stating that: "our framework, which is rigorous yet flexible in application, enables us to evaluate any school of thought within IR” (Devlen, James y Özdamar, 2005, p. 173).
} 


\section{THE ANALYTICAL TOOL}

In their 2005 paper, Devlen, James and Özdamar propose a synthesis of the most important ideas developed by philosophes of science in order to identify a "research enterprise". In doing so, they identify three characteristics of the concept:

(a) a set of assumptions with parametric status, known as the Hard Core; (b) rules that prohibit certain kinds of theorizing, labeled as the negative heuristic; and (c) a series of theories, called the positive heuristic, for which the solved and unsolved empirical problems (along with anomalies) focusing on the description, explanation, and prediction of actions and events continue to accumulate. Each of these major components will be explained in turn with appropriate linkages to the classic expositions noted a moment ago (Devlen, James and Özdamar, 2005, p. 172-173).

From those three characteristics, it is important to note that the authors derive five criterions that allow for the qualification of a set of academic proposals as a "school of thought".

Following this model, the first phase in this endeavor is therefore to determine the worldview from which the reasoning stems. In other words, before anything else, we must be able to identify the way in which a particular group of academics understands the way the world is functioning. Devlen, James and Özdamar propose that this particular way of thinking and understanding the world can be reduced to a gestalt ("figure", in German), a specific word or phrase such as "Marxism" (Devlen, James and Özdamar, 2005, p. 173).

The idea that knowledge - of any kind - stems from a specific situation or ideological context is not new and dates back at least to Thomas Kuhn's first attempts to identify a paradigm. For him, a paradigm consists of a "strong network of commitments - conceptual, theoretical, instrumental and methodological" (Kuhn, 1962, p. 42) that include "quasi metaphysical" ones (Kuhn, 1962, p. 41). A way to summarize it could be as follows: a paradigm is a set of shared convictions between members of the same scientific discipline about the legitimate problems and methods of a specific field of study. Thus, a school of thought is always entrenched in a specific worldview. Following the Hungarian sociologist Karl Mannheim, specifically his book "Ideologie und Utopie" published in 1929, one could also say that, as the late Edward Shils noted in 1974 (p. 84), "every society and epoch ha[s] its own intellectual culture, of which every single work produced in it [is] a part. In this imposing medium the individual mind and its works [are] only instances of the "objective spirit" or culture into which they were born. The individual's mind, the individual's imagination, the individual's power of reason and observation [are] only fictions" 4 .

In the same way, Nicholas G. Onuf identified three "paradigm theories", that is, three paradigms that delimit the researcher's

I am indebted to Arlene Tickner for highlighting this aspect to me. 
range of interest and a series of legitimate questions to which the researcher is deemed to respond. Those "paradigm theories" are not directly related to International Relations, rather they are imports from other fields of human enquiries.

The first "paradigm theory" is microeconomics. Its principal characteristic is its formality and explicative power. Those two traits result from the postulate that individuals are autonomous and act rationally - using all material means at their disposal - in order to maximize their benefit. The second "paradigm theory" acknowledged by Onuf is Marxism. It bases itself on the postulate that social order is the result of an uneven repartition of productive capacities. Finally, yet importantly, there is the political society "paradigm theory". This one irrevocably links the sine qua non of society (the unavoidability of rules) and of politics (the persistence of asymmetric social relations) in the conduct of the analysis.

For us, those elements will open the way to identify one criterion of the evaluation of a school of thought: its paradigmatic-theoretical affiliation.

Following Devlen, James and Özdamar's proposal, ontology derives from worldview. Here, ontology is defined as a shared way - between members of the same research enterprise - of observing the world (p. 173). In other words, ontology determines which variables will be considered in a study - may it be the problem to solve in the study, the relevant units for the study or the limits of the study.

At this point, it is import to note that worldview, ontology and what Onuf calls a "paradigm theory" are intimately linked.
In their study, Delven, James and Özdamar do separate worldview and ontology in two distinct criterions. I intend to reformulate those two first steps in order to give way to a more open reflection about theorizing. The first criterion of the model suggested here will therefore be the identification of a worldview and an ontology. The second criterion will include Onuf's reflections and will be reformulated here in terms of "paradigmatictheoretical" affiliation.

Once worldview and ontology are determined, Delven, James and Özdamar enjoin us to consider the "Hard Core" of the proposal (third criterion). This Hard Core corresponds to what Kuhn called a "paradigm", that is, a fidelity to a set of basics suppositions (axioms) shared between the researchers that participate in the same research enterprise. Here, the three authors remind us that: "These axioms are not brought into question unless one or more is found to be at odds repeatedly with the propositions derived from them" (Devlen, James and Özdamas, 2005, p. 173).

Once established what "is" the proposal, one should be able to identify what it is not. The "negative heuristic" (Lakatos, 1971) (fourth criterion), has to be understood in the same lines of Popper's falsification (Popper, 1969); that is, we should be able to identify the rules for work to proceed within a particular research enterprise. Therefore, negative heuristic will help us recognize the investigative methods used within a specific school of thought.

Lastly, the fifth criterion, the "positive heuristic" consists of what the research enterprise aggregated to knowledge. In other 
words, we should be able to spot what the school has achieved in term of describing, explaining, and predicting.

Devlen, James and Özdamar (2005, p. 173) synthetize their analytical proposal as follow:

Taken together, a research enterprise reflects a basic belief about the world and how it operates, understood in terms of a worldview and ontology. Paradigms within the research enterprise compete, each offering a series of theories (for example, T0, $\mathrm{T} 1, \mathrm{~T} 2 \ldots$...) that, if successful, include later entrants that surpass those arrived at earlier in terms of solved empirical problems. Such a process, in essence, is what is meant by the identification of progress in the study of the social world.

The three authors propose a table in which they point out the relation between the various concepts:

\begin{tabular}{|l|l|l|}
\hline \multicolumn{1}{|c|}{ Concepts } & \multicolumn{1}{|c|}{$\begin{array}{c}\text { Degree of } \\
\text { Aggregation }\end{array}$} & \multicolumn{1}{|c|}{$\begin{array}{c}\text { Summary of } \\
\text { Meaning }\end{array}$} \\
\hline Worldview & Most general & $\begin{array}{l}\text { Understood by } \\
\text { gestalt }\end{array}$ \\
\hline Ontology & General & $\begin{array}{l}\text { Identification of } \\
\text { what is to be obser- } \\
\text { ved: main issues, } \\
\text { units, unit boun- } \\
\text { daries }\end{array}$ \\
\hline Paradigm & Intermediate & $\begin{array}{l}\text { Designation of } \\
\text { parameters }\end{array}$ \\
\hline Theories & Specific & $\begin{array}{l}\text { Designation of key } \\
\text { variables }\end{array}$ \\
\hline Hypotheses & Most specific & "If/then" statments \\
\hline
\end{tabular}

Source: Devlen, James and Özdamar (2005, p. 174).
In this table, we observe that the act of theorizing itself is second-to-last before initiating the proper analytical work. As it stands and before proceeding, it seems necessary to remember some basic elements of the definition of the concept of theory. To do so, I will repeat two quotes traditionally used in order to define what theory is, the first one from Charles Sanders Pierce, the second from Karl Popper.

From Pierce (Pierce, Ms 692, cited in Sebeok, T.A. y Umiker-Sebeok, 1980: 23):

Looking out of my window this lovely spring morning I see an azalea in full bloom. No, no! I do not see that; though that is the only way I can describe what I see.

That is a proposition, a sentence, a fact; but what I perceive is not a proposition, sentence, fact, but only an image, which I make intelligible in part by means of a statement of fact. This statement is abstract; but what I see is concrete. I perform an abduction when I so much as express in a sentence anything I see. The truth is that the whole fabric of our knowledge is one matted felt of pure hypothesis... Not the smallest advance can be made in knowledge beyond the stage of vacant staring, without making an abduction at every step.

What Pierce is trying to explain is that without theory, we - human beings - would not have the capacity to arrange, in a consistent manner, our own experiences. Theory is inescapable. Theory is an integral part of our lives. Theory is what allows us to give sense to our daily actions. What makes the difference between scientific reasoning and day-to-day experiences is that, for scientific thinking to be pertinent, theorizing has to be proactive and 
intentionally sought in order to get us closer to a "true" understanding of reality.

Popper's definition, generally accepted, gives us a comprehensive summary of what is a theory: "Theories are nets cast to catch what we call "the world": to rationalize, to explain, and to master it. We endeavour to make the mesh ever finer and finer." (Popper, 1959, p. 59)

Once defined the general frame that will help us "understand" the world, follow the designation of key variables. Those variables are concepts and through the act of conceptualization, we have to outline them properly. If we understand the construction of meaning as an architectural project, concepts are "bricks" and theory is the "plumb-line".

What adds value to the theoretical proposal in a scientific discipline is the fact that the precision of generalizations made thanks to it, can, and will, be submitted to the falsification process. No matter if those generalizations were constructed from individual cases (inference from the particular to the universal: induction process) or that individual cases are explained from a general proposal (from universal to particular: deduction process), in the realm of science, it is admitted that what makes the difference between a prejudice and a theory is the verification process.

Nonetheless, as Hans Joas and Wolfgang Knöbl (Joas and Knöbl, 2009, pp. 6-7) indicate:
As Popper lays out (...) in the case of most scientific problems we cannot be certain whether a generalization, that is a theory or hypothesis, truly apply in all cases. (...) As a rule, universal statements cannot therefore be confirmed or verified. To put it another way: inductive arguments (that is, inference from individual instances to a totality) are neither logically valid nor truly compelling arguments; induction cannot be justified purely in terms of logic, because we are unable to rule out the possibility that one observation may eventually be made that refutes the general statement thought to be corroborated. (...) Popper's position was thus that while generalizations or scientific theories are not ultimately provable or verifiable, they may be checked against reality intersubjectively, that is, within the research community; they may be repudiated or falsified. (...) Popper is simply of the opinion that there is little point in entering into a scientific dispute about [a statement that cannot ultimately be disproved].

This remark is important because it leads us to take into account the impact of conceptualization on the theorizing process. Nowadays, academics consider a theory as "scientific" only if it passes the falsification test. In this context, a generalization or theory constructed from individual cases that need a restricted conceptual definition to make sense of reality is impossible to refute and, therefore, cannot gain the status of "research enterprise".

This tendency puts the reflexive methodological approach in a position of relative

Popper's definition is essentially positivist. Nonetheless, one can modify the terms of the definition in order to make it more inclusive or reflexive. The use of "understanding" rather than "explaining" -the proper Popperian term- is the result of this endeavor. Theories do not only help us explain but also interpret better; that is, understand. 
debility against the positive one $e^{6}$. The debate about the degree of scientificity of those two methodological approaches is not new in our discipline and has been carried out along the lines of great debates - or inter-paradigmatic debates (Lapid, 1989). In fact, this debate still rages on today. In this paper, far from discarding reflexive contributions, we want to acknowledge the fact that the mainstream tendency is currently positivist. Furthermore, Cynthia Weber observes a process of "gentrification" of the minds in International Relations, that is, a stronger and stronger acceptance of reflexive methodology that leads to its very disappearance.

\section{Weber writes:}

To make sense of this argument, think of the discipline of IR Lapid was writing about twenty-five years ago as a city in which various IR theories inhabited different neighborhoods. IR's upscale neighborhoods were populated by mainstream theories like (Neo)Realism and (Neo)Idealism, while downscale neighborhoods were populated by intellectual immigrants into IR (Marxisms, feminisms, queer theories, critical race theories, postcolonialisms, and poststructuralisms) who lived together in a kind of pre-gentrified NYC East Village, where they wielded far less disciplinary capital (e.g., in publishing and employment) than did their upscale colleagues.

Just after Lapid's publication of 'The Third Debate', the discipline was caught off guard by the end of the Cold War. This had the unlikely effect of transforming the East Village of IRs into a go-to location for upscale IR theorists seeking out new theoretical and methodological insights that might rescue the discipline. Their visits put downscale/critical IR on upscale IR's map as an up-and-coming area, thus raising the disciplinary capital of some critical IR scholars and generating 'enhanced reflectivity' within the discipline. Yet over the years, upscale IR scholars increasingly viewed their engagements with downscale/critical IR as incommensurable, non-productive, hostile and dangerous (eg., Holsti, 1985; Keohane, 1989 and in reply Weber, 1994). This lead them to brand downscale/critical IR as failing the discipline because it detracted from IR's disciplinary goals (Keohane, 1998; Weber, 2014).

Here, we use Cynthia Weber's argument in order to show that we are aware of this metatheoretical dilemma. We have no intention of sidelining Latin American contributions only on the bases that they were formulated outside of the "scientific" orthodoxy. In this paper, our posture will be the same as Allen Cordero's on Sociology in Latin America:

6 In order to encompass the large variety of tendencies that understand the world as a reflection of a worldview, Robert Keohane coined the term "reflective". In his own words: "I will give them a label (...) "reflective", since all of them emphasize the importance of human reflection for the nature of institutions and ultimately for the character of world politics." (Keohane, 1988, p. 382). The transformation of the term in "reflexive" occurred later. In 2011, Inanna Hamati-Ataya (Hamati-Ataya, 2011, p. 261) defined reflexivism as "a systematic socio-cognitive practice of reflexivity, and reflexivity as the scholar's conceptual/methodological response to her acknowledgment of the mutual reflectivity of knowledge and reality, that is, of inscription of social divisions, interests, and concerns in cognitive categories of understanding and analysis, and vice versa." Therefore, reflexivists can be postmodernists, poststructuralists, postpositivists, critical and/or neo-marxists. 
Regardless of the misinterpretations that Kuhn's thinking suffered, it is important to recognize that he is very important not only because of his elaborations but also because of his capacity to generate a philosophical dialogue between a variety of branches of scientific and social enquiry. In this sense, for us, philosophies that possess a capacity to generate reactions from other disciplines are better than those that are inward-looking ${ }^{7}$ (Cordero Ulate, 2008, p. 2).

Thus, the ultimate benchmark in our assessment of the existence of a Latin American school of thought will be the comparative utility of its proposals.

\section{LATIN AMERICAN THINKING IN INTERNATIONAL RELATIONS}

\section{A) WORLDVIEW AND ONTOLOGY}

Let us begin the analysis. First, we have to assess the basic beliefs Latin American academics have about the world and the way it functions.

A number of our colleagues south of the Rio Grande think that the importance of theory has been, and is, overestimated. In fact, a tendency to reject any methodological instrument or theory constructed outside the region has arisen with force in the last two or three decades. From Juan Carlos Puig (1984) to Raúl Bernal-Meza (2010), the idea that it is impossible to grasp satisfactorily the Latin American reality using theories manufactured in the "North" has entrenched itself in the collective psyche of Latin American internationalists.

Expressing this rejection, the Argentinian academics Maria Elena Lorenzi and Maria Gisela Pereyra Doval wrote in 2013 that $^{8}$ (Lorenzini and Pereyra Doval, 2013, p. 11):

From our point of view, referring to the ethnocentric nature of International Relations is right because it allows us to become aware of the preponderancy of the European and North American perspective in the discipline. Ethnocentrism, therefore, can be understood as the attribution of superiority to one society - European and/or North American - over the others - Latin American, African, and Asiatic - and reveals itself as the constant feature in social sciences and International Relations?.

Even worse, according to the Brazilian Amado Cervo (2008), the use of theories formulated

7 “(...) [I] ndependientemente de las malas interpretaciones que se han hecho del pensamiento kuhniano, nos parece que Kuhn fue un filósofo muy importante tanto en virtud de sus elaboraciones como por la capacidad de generar comunicación filosófica con variadas ramas del quehacer científico y social. Es obvio en este sentido que, desde nuestro punto de vista, valoramos de manera más positiva a las filosofías que tienen la capacidad de generar reacciones por parte de otras disciplinas, que aquellas filosofías 'encerradas en sí mismas.'

$8 \quad$ It is important to note here that Latin America is understood as different from the West by the authors. The same consideration applies in Tickner \& Wæver (2009) and Tickner \& Blaney (2012). As I will discuss later, this separation is not as evident as it would seem.

9 "Desde nuestro punto de vista, conviene referirse al carácter etnocéntrico de las Relaciones Internacionales ya que nos permite dar cuenta de la preponderancia de la mirada europea y norteamericana a la vez. El etnocentrismo, 
outside of the region tend to reproduce the dominant ideology for the benefit of core states. In 2013, Cervo wrote (2013, p. 154):

In the state they are in, International Relations theories have a limited explicative, normative, and policy-making capacity because researchers are identifying interests, values and conductive patterns that stem from multiple points of origin that in turn nuance their interpretation implicitly or explicitly. Between Nations, the diversity of those factors is of the upmost importance. This objective observation makes it impossible to attain any universal theory ${ }^{10}$.

We must discuss this worldview ${ }^{11}$ and the possible consequences it has on the assessment we can do of the existence of a Latin American school of thought. Cervo $(2008 ; 2013)$ proclaims the necessity to redefine concepts depending on a national or regional perspective. His goal is to attain a greater correctness when "interpreting" reality. This reasoning, affiliated to reflexivism, is no stranger to us and is, as we argued before, accepted in the discipline of International Relations.
Nonetheless, this mark of goodwill - his endeavor in identifying a theoretical proposal that stems from local contexts - is problematic. Every time academics try to outline a nation or a region, a problem of legitimacy and veracity of those limits emerges. Take "Africa" for instance (Frasson-Quenoz, 2014). From the seemingly harmless question of "Who is member of the African region?", a series of heated debates branch out. As Mansfield and Milner pointed out (Mansfield and Milner, 1999), academics have not been able to establish a consensus on the definition of the concept of region. Some focus their attention on the geographical proximity, as do Mansfield and Milner (1997). Others highlight the relevance of economic and political interdependence (Soligen, 2008; Dieter, 2009; Nel and Steven, 2009). Instead, another group tends to prioritize security dynamics (Morgan, 1997; Buzan and Wæver, 2003). Obviously, some will object that those reflections, those theoretical proposals, come from the North and that, in consequence, they do not apply to Latin America. In order to demonstrate

entonces, es entendido como la atribución por parte de alguna sociedad -europea y/o norteamericana- de una superioridad respecto a las otras sociedades -latinoamericanas, africanas, asiáticas- y ha sido una característica constante en las ciencias sociales y en las Relaciones Internacionales."

10 "En el estado en el que se encuentran, las teorías de las relaciones internacionales están limitadas en su capacidad explicativa, normativa y decisoria, dado que los investigadores más recientes avanzan en la identificación de intereses, valores y patrones de conducta de múltiples procedencias que introducen en su interpretación, de un modo implícito o explícito. Entre las naciones, la diversidad de estos tres factores es preponderante. Una constatación objetiva tal hace imposible cualquier teoría de alcance universal."

11 Here, one can speak of worldview -a way someone thinks about the world- because this statement rejects the idea of universality and binds together interest, values and conductive pattern. Those elements are the fundament of his reflection. 
that the same problem exists no matter where, I will use the Brazilian example. Trying to respond to the question "Is Brazil part of Latin America?" the Brazilian historian Leslie Bethell (2009: abstract) showed that:

...neither Spanish American nor Brazilian intellectuals, and neither Spanish American nor Brazilian governments considered Brazil part of "América Latina" - which generally referred to Spanish America only - at least until the second half of the $20^{\text {th }}$ century, when the United States, and the rest of the outside world, began to think of Brazil as an integral part of a region called "Latin America".

We could follow the same argumentative lines on the matter of nation and national thinking. Every Latin American state is a multinational state. At the same time, in every single case, official decision-making process excludes some national minorities that live within the limits of the state's territory because their interests and/or worldviews have no place in high spheres of power.

To proclaim the existence of a national thinking generates the same difficulties as to assert the existence of a "national interest". We can understand the concept of "national interest" in many different ways. However, in no way can the "national interest" ensure the expression of all the interests of those that live within the borders of the state. As Robert Jervis noted writing about the concept of "national interest" as defined by Hans Morgenthau (Jervis, 1994, p. 855), the American "national interest" has always been in function of the interest of one particular group of people. This group may have been the Irish or the Germans between the late $19^{\text {th }}$ and early $20^{\text {th }}$ century or the federal administration during the Cold War. In any case, the American "national interest" was never truly national. Said in another way and coming back to the Brazilian "national thinking", even if the definition of concepts corresponds to a certain worldview or ontology (defended by those that proclaim themselves legitimate to do so in Brazil), it does not correspond to a theorizing act, but rather to the expression of a particularism. This expression of cultural particularism only has some scientific relevance when the contextual definition of concepts can provide some certainty about the nature of the world, whether it be materially or socially defined; that is, when it allows for generalization.

Clearly, Maria Elena Lorenzini and Maria Gisela Pereyra Doval are right to highlight the eurocentrism of the theoretical reflection in International Relations. In fact, this affirmation is so commonplace that it is one of the basic arguments of some North American academics such as Robert Vitalis (2015). However, this does not constitute proof that theory is useless once extracted from its original context of application. A contrario, to apply Western theoretical proposals to foreign contexts allows for their reevaluation and thus, to roam along the continuum of Aggregation - which is in fact what theorization is about. The same logic applies to the case of Latin American thinking. Their proposals should allow the process of aggregation to take place, and even though the scientific community recognizes the validity of the inductive reasoning, this cannot be a justification for solipsism. If it were, the 
only option left for Latin Americans would be to reject International Relations as a valid field of scientific enquiry. Some have done so before: the deconstructionists ${ }^{12}$.

Not all Latin American academics accept this worldview. In Brazil and in another scientific discipline (Natural History), the same debates gave its rhythm to the human reflection during the $20^{\text {th }}$ century. In 2005, the Brazilian anthropologist Luis Fernando Dias Duarte wrote (Dias Duarte, 2005):

At the beginning of the Republican period, the creation of the Museu Paulista had already announced very clearly this dimension in the relation between Nation, Science and Nature. Its founder, Herman Von Ihering, had underlined very clearly his intention to create an institution "purely" scientific (in opposition to an institution in which this intention was tainted by the dimension of national representation, as was the case for the Museu Nacional) ${ }^{13}$.
What I mean to stress here is the fact that the debate that rages on between the validity of situated knowledge and scientific/universal knowledge is not alien to Latin America, and that, in fact, this debate has its roots in Europe:

In the middle of the $18^{\text {th }}$ century, one could already discern in the countries of central Europe a demand for reestablishing a link between the "knowable" ("le connaissable") and the "sensitive" ("le sensible'), and a conscientiousness of the specificity of the properties of each level of reality, through the form of "singularities" - that is to say, through an odd alliance between the preference given to individual parts and the consideration of the totality ${ }^{14}$ (Dias Duarte, 2005).

In other words, what Arlene Tickner and David Blaney (Tickner and Blaney 2012: 107) identified in 2012, seems to confirm itself here: " $[\mathrm{T}]$ here is an entrenched and

12 In order to clarify this movement, one could mention Jacques Derrida and Michel Foucault. The French scholars wrote about international relations but for them this was not about some particular global scenery (state, sovereignty and balance of power), but rather about continuities in human interrelations (genealogy of language and historical processes). As James Der Derian (2007) noted: "Foucault et par extension tous ceux qui pouvaient reprendre ses propositions dans leurs travaux représentent une menace pour les relations internationales (...) parce qu'il ébranlait la sacro-sainte Église du réalisme philosophique qui sous-tend les écoles de pensée dominantes en relations internationales." Indeed, in the sixties and seventies, some scholars, followers of Foucault and Derrida, rejected International Relations as a scientific discipline and proclaimed that International Relations should be renamed or abandoned.

13 "La création du Museu Paulista au début de la période républicaine avait déjà annoncé très clairement cette dimension des rapports entre nation, science et nature. Son fondateur, Hermann Von Ihering, avait souligné très clairement son intention de créer une institution 'purement' scientifique (par opposition à une institution où cette intention était souillée par la dimension de représentation nationale, comme le Museu Nacional).»

14 "Vers la moitié du $18^{\mathrm{e}}$ siècle, on pouvait déjà discerner dans les pays centraux de l'Europe une demande de retour aux liens entre le connaissable et le sensible et une conscience de la spécificité des propriétés de chacun des niveaux de la réalité, sous la forme de 'singularités' - c'est à dire, par le moyen d'une curieuse alliance entre le privilège de la partie individuelle et la considération de la 'totalité'." 
palpable global division of labor whereby the center is seen as a main producer of theoretical knowledge and the periphery a simple consumer."

At any rate, it can be argued that the will of some Latin American academics to distance themselves from the European theoretical reasoning can manifest itself only because, in the West, the necessity to integrate "le sensible" and "le connaissable" has been recognized since the beginnings of the liberal movement of the Enlightenment. As it stands, and to the detriment of those that sustain the contrary, even the validity of situated ontology is an integral part of the Western worldview.

A specific worldview is proclaimed by some Latin American academics. From this proclaimed worldview, a specific ontology is derived. The view is that Latin Americans are different from Europeans and North Americans and that this difference results in the existence of an alternative "Latin American world", a world that needs describing.

\section{B) Paradigmatic-theoretical affiliation}

The Latin American worldview and ontology discussed, we will turn our attention to its "paradigmatic-theoretical" affiliation. We could fix our attention on many different proposals, but we will focus on those that proclaim a will to theorize differently or those that reject the validity of theorization because they consider theorizing as a reproductive act of the current social structures.

Here, the reflection in terms of dependence are the most significant. In this particular Latin American trend, the concept of "Autonomy" has a special relevance. During the seventies, with authors like Helio Jaguaribe, Celso Furtado, Torcuato Di Tella, Oswaldo Sunkel, Fernando Cardoso and Enzo Faletto (Jaguaribe et al., 1972) the reflection in terms of autonomy made its way in the Latin American landscape of International Relations. From then on, this concept became the most commented and worked on in the south of the continent.

We could extend our comments to the whole set of Dependencia theory - from economics, politics, social and cultural issues but the most relevant to our study are the main forms that took the dependence reasoning in International Relations through the concept of Autonomy.

The first moments of the incorporation of the Dependencia theory in International Relations debates were, as we said, the seventies (Cardoso and Faletto, 1969) but its precursor was, without a doubt, Raúl Prebish ${ }^{15}$. As far as we can tell, apart from his fundamental demonstration of the existence of a relation of dependence between states through their economic relations, the most noteworthy element of the Argentinian's proposal is that it was constructed through systematic empirical research,

15 It could be argued that Prebish was not exactly a theorist, but the fact is that he went down in history as the inspirational figure of the Dependencia theory. 
narrowed to the Latin American region ${ }^{16}$. At the same time, his conclusions had a global reach that allowed for a reinterpretation and a reevaluation of "reality".

After the inception and its first failures in the attempt to transcribe the theory into public policies, Juan Carlos Puig was the first to take back possession of the idea of dependence through his definition of the "Doctrine of Autonomy" (Puig, 1980). For him, autonomy means the search of some latitude ("margén de maniobra") in the midst of a dialectical relation between the necessity of insertion in international regimes and the quest for freedom. Thus, Autonomy is an instrument made available to peripheral states in order to break free from subordination. In this definition of the "theory" of autonomy the basic element of the cepalino ${ }^{17}$ reasoning surfaces: states are searching for freedom but always "having in mind the current structural constrictions as well as the domestic conditions" (Ovando Santana and Aranda Bustamente, 2013, p. 721).

Based on Puig's foundational formulation, Latin American IR academics - essentially Argentinians and Brazilians - never ceased to redefine the concept of Autonomy. This exercise in definition is not, per se, a problem.
Nonetheless, it makes it necessary to mention some of the most important redefinitions the concept has endured before proceeding to the next point of our assessment of the existence of a Latin American school of thought in IR.

I will present here five of those, which are not presented in chronological order nor in order of importance ${ }^{18}$.

After Puig's, one can mention Escudé's reinterpretation of the concept of Autonomy (Escudé, 1992). For him, autonomy is a question of cost and of a state's capacity to overcome it. In Escudés proposal, all states, including those at the periphery, are trying to maximize their capacity to take decisions freely. However, this search for freedom on the international scene is always limited by the state's capacity to overcome the costs it implies on the domestic scene in terms of welfare. For Escudé this tension between will and capacity is what defines a state's latitude (margén de maniobra).

Roberto Russell and Juan Gabriel Tokatlían's proposal of "relational autonomy" (Russell and Tokatlían, 2001 and 2002) was formulated in hopes of increasing "the capacity and disposition of one state to take decisions in concert with others, and of their own free will, in order to overcome together situations

16 Here the definition of region is not a problem because Prebish led his research under the shelter of the Economic Commission for Latin America and the Caribbean (CEPAL, Spanish acronym), one of the five regional commissions of the United Nations. Here, the definition of region is given to us.

17 Adaptation of the acronym of CEPAL.

18 It is important to mention that Mexican works are not included in this study. This omission is deliberate but does not invalidate the core of the reasoning. Obviously, including Mexican works is desirable and should be done at a further point. 
and processes that have impacts in and out of their borders." (Russell and Tokatlían, 2002, p. 176). The main difference between this definition of autonomy and the last two is that here the two authors are directly influenced by the feminist's definition of power. For them, power is not an instrument of domination, rather a tool of coordination of emancipatory action (Tickner, 1988: 434). It is important to note that the definition of autonomy they give is based on a perception that the latter characterizations of Autonomy needed to be reformulated in order to "adapt the notion to new global and regional circumstances" (Russell and Tokatlían, 2002, p. 160).

Mario Rapoport's notion of autonomy correspond to a historical and sociological reading. In fact, Rapoport's depiction seems to be much closer to Prebish's because Rapoport leads us to consider the concept of autonomy as a manifestation of the will of submitted peoples to break down unjust social structures. Following Rapoport's argument, one is led to understand the importance of the concept in Latin American thinking not as a tool, but as a manifestation of social nonconformity. This rebellious expression is as much the consequence of the imposition of economic structures as well as ideational ones by core/ Western states (Rapoport and Míguez, 2015).
Others, like Tomassini (Tomassini, 1989), Lechini (Lechini, 2009) and Pastrana and Vera (Pastrana and Vera, 2012) have a more political-economical bias in their understanding of the concept of autonomy. Lechini wrote (2009, p. 67):

South-South cooperation or the cooperation between peripheral states refers to a general modality of political cooperation (...) which aims at obtaining more collective bargaining power, in defense of their interests. The basic idea is that it is possible to create a conscience of cooperativeness that will allow countries from the South to strengthen their negotiation capacity with the North through the gain of some latitude on the international scene and with it more decisional autonomy in order to confront and resolve common difficulties. (...) Understood in this way, it applies to a variety of topics of which economics, commercial, technical, scientific, academic, and diasporic are the most important ${ }^{19}$.

Brazilians, on the other hand, tend to prefer the strategic and tactic dimensions of the concept. In fact, they focus their attention on the potentialities the concept entails in terms of policy. The redefinition of the concept of Autonomy as "autonomy by distance" and "autonomy by participation" (Fonseca, 1998), the evaluation of those two redefined concepts

19 “...la cooperación Sur-Sur o cooperación entre países periféricos refiere de modo general a una cooperación política (...) para obtener un mayor poder de negociación conjunto, en defensa de sus intereses. Se basa en el supuesto que es posible crear una consciencia cooperativa que les permita a los países del Sur reforzar su capacidad de negociación con el Norte, a través de la adquisición de mayores márgenes de maniobra internacional y con ellos, mayor autonomía decisional, para afrontar y resolver los problemas comunes. (...) De este modo puede abordarse y objetivarse en variadas dimensiones, entre las cuales se destacan la económica-comercial, la técnica y científicotecnológica, la académica y la diaspórica”. 
made by Aloizio Mercadante (Mercadante, 2013), or its reformulation as "autonomy by diversification" (Vigevani and Cepaluni, 2007), was done in hopes of adapting the Brazilian Foreign Policy to an ever changing international context. Their goal is not to propose an encompassing theory rather to make sense of the political options chosen by their governments - from Fernando Henrique Cardoso to Dilma Rousseff - and explain what should be done in order to achieve the much elusive autonomy.

At this point, and before taking on the third criterion of our assessment, it is necessary to remind the lector that the understanding Latin American scholars have of the concept of Autonomy has as much to do with the Prebish-Singer thesis as it does with Nikolai Bukharin's ${ }^{20}$ proposal. In 1915 (Bukharin, 1977), the soviet suggested that the world was divided - through its economic structure - between "cities" - that are industrialized countries - and the "countryside" -composed of the agricultural regions of the world - and that, for the latter, development would only be achievable through a reevaluation of the terms of trade.

\section{C) What is the Latin American proposal? (HARd Core)}

Considering what have been said, the Hard Core of the Latin American proposal relates to the basic set of the Dependencia theory:
1. Core states subdue those of the periphery;

2. Dependency mainly manifests itself in economic interactions but also in all other sectors of human activity;

3. As a result, there can be no political independence without economic independence;

4. Consequently, the main objective of public policy has to be the termination, or at least the limitation, of dependency.

However, the fidelity Latin American academics manifest to this "Hard Core" includes a profound acceptance of the idea that state is the most - if not the only - legitimate entity to wield power.

In fact, none of the proposals presented earlier take into account the possibility that autonomy could be obtained thanks to a non-state actor. Arlene Tickner defines this axiom as "the primacy of lo práctico" (Tickner, 2008) which consists of putting the state and its necessity first. The practical utility of the conceptual proposal encompasses a wide variety of topics - which may be economics, politics, social or cultural issues- and its efficiency is always valued in terms of its propensity to be translated into public policies that will compensate shortcomings - invariably understood in material terms.

In summary, the Hard Core of the Latin American proposal is inductive. Starting from empirical observation, the researcher should focus on the relations of domination that

\footnotetext{
20 Without entering into historical considerations, I think that it is important to remember that Bukharin was an eminent member of the soviet party and that he was considered, after 1924, the leader of the right wing and that he died, in 1938, accused of being an agent of imperialism.
} 
exist between states, on the impact this type of relations has on the uneven repartition of material resources and the reproduction of unjust social structures, and finally on the task of identifying the processes through which those social structures could be changed. This Hard Core can be summarized with one concept: Autonomy.

\section{D) What the PROposal is NOt? (Negative HEURISTIC)}

This proposal is not deductive because it assumes - in its analytical process - the primacy of local context over the theory.

Aside from this, it is very difficult to exclude definitely any other methodological elements. As I mentioned before, disputes are profound between Latin American academics. In fact, one of the most serious accusations a "Latino" academic can formulate against another is that he/she follows Western theories or that he formulates a theory. For instance, Puig was accused of being a realist, and Escudé to be a defender of the liberal order. Along the same lines, we could classify Russell and Tokatlían as critical theorists or Lechini as a constructivist. But, surprisingly enough, in this game of mutual "name-calling", Latin American sociologists seem to stay unharmed. Nowhere is to be read that Mario Rapoport is not a true Argentinian academic because he follows the historical-sociological methods he learned in France, on the contrary ${ }^{21}$.
One of the questions Iraxis Bello and Francisco Javier Peñas Esteban formulate in their foreword of the Relaciones Internacionales journal number 22 is quite noticeable. When the two scholars ask: Do academics from the South elaborate "knowledge maps" and original theories in order to solve local problems or are they simply using the canon in IR? Tickner and Blaney have an interesting response. For them, Latin American academics do follow IR's canon (Tickner and Balney, 2012). I would argue that, in fact, they do not follow one canon but a variety of canons (realist, liberal, etc.). This leads us to say that Latin American's Hard Core is more of a disposition to think international relations in terms of domination rather than to accept an established Marxist/Dependentist rule as the only theoretical canon. In other words, Latin Americans are neither independent from Western theoretical proposals nor obedient to only one canon.

Contrary to what Bello and Peñas Esteban hint at, Cox's traditional division between, on the one hand, problem-solving theories (traditional theories like Realism and Liberalism) and, on the other, Critical Theories (those theories that always tend to evaluate their own political impact on the object) is not adequate to assess Latin American thinking in International Relations. Academics from Latin America do try to solve problems (they usually try to propose new public policies) and their proposals do not include an

21 Mario Rapoport has been celebrated, through a long period of time and numerous national awards, as one of the major Argentinian academics. 
auto-reflexive dimension (they often deny the necessity and/or the reach of theorization). In fact, very few of them do interrogate the political reach of their own reflection on state's autonomy. There is a tendency to minimize the fact that the work they do around the concept of autonomy legitimizes the state-centric reading of human relations, reading that, one could argue, ensures Western hegemony over human interrelations and over the scientific discipline of International Relations. From this discussion, one can highlight the fact that Latin American proposals are not critical in essence. If those proposals try effectively to free southern states from northern domination, they do not contest the fact that states must be the first beneficiary of this freedom.

\section{E) WHAT DOES THE RESEARCH ENTERPRISE AGGREGATE TO KNOWLEDGE? (POSITIVE HEURISTIC)}

In Delven, James and Özdamar's frame of analysis, the critical moment for the assessment of the existence of a school of thought is when one tries to identify the contributions it may have made to knowledge.

Once Latin American thinking in International Relations presented through the concept of Autonomy, we do concur with Cervo's conclusion about Brazilian reflection (2013). Yes, “Brazilian's concepts' systematization applied to the country's international insertion (...) is understood as making an intellectual contribution to the study of international relations." In fact, we not only concur with him, we also extend this conclusion to all Latin American thinking in International Relations.
There is no doubt that Latin Americans academics aggregate knowledge in the discipline. Thanks to their work, we know more about the concept of Autonomy then before, its various definitions, its impact, its origin, and the modifications that it should undergo in order to attain a state of greater harmony in human relations. However, this participation to the aggregation process is not deliberately different from the one traditionally accepted. Here I will enter into more detail.

Because the essential foundation of Latin Americans' proposals is the empirical observation of specific contexts and because they proclaim that their proposals have no universal reach or because they do not tend to apply their conclusions to other cases, generalizing is impossible or not demonstrated. Therefore, on their own, those contextualized proposals have no scientific value.

Nonetheless, as we demonstrated earlier, we can link each proposal to a particular Western theorization (may it be realist, liberal, constructivist, critical or sociological; to mention those that figure in this paper). Understood this way, each proposal formulated in Latin America is aggregating to the universal knowledge, to the scientific project of International Relations. Thus, Latin American thinking has a scientific value, not for its intrinsic virtues, but rather because they allow for the falsification process to take place within the scientific community of International Relations. In other words, the ethnocentric/ Western knowledge can be evaluated when it is confronted by Latin American contexts.

Amitav Acharya (Acharya, 2011) described this paradox perfectly. Latin American 
academics tend to understand their work in terms of "normative localization" when they should, in fact, understand it in terms of "normative subsidiarity"22.

With his proposal, Acharya - an Indianborn Canadian academic, specialist of the Global-South and ex-president of the International Studies Association - differentiates between the norm localization process (that leads native academics and decision-makers to close the gap between local beliefs and universal dogmas) and the process of norm "subsidiarization" (that makes local participants part of the construction of universal dogmas).

Graphically, the idea of subsidiarity establishes a special relation between local and global contexts.
Here, one understands that the cultural background that leads a particular individual to comprehend the world in a different fashion (basis of the analysis) can constitute, depending on the case, as much as a rejection of the transnational norm (in our argument, theories of International Relations) as well as an acceptance or reformulation of it (a participation in the aggregation process). In fine, Latin American academics do participate in the universal scientific process (theorization) but in most cases, they do so because they reject European and American proposals (fulfilling the task of falsification within the academic community) rather than accept or reformulate them.

\section{ACHARYA'S PRINCIPLE OF NORM SUBSIDIARITY}

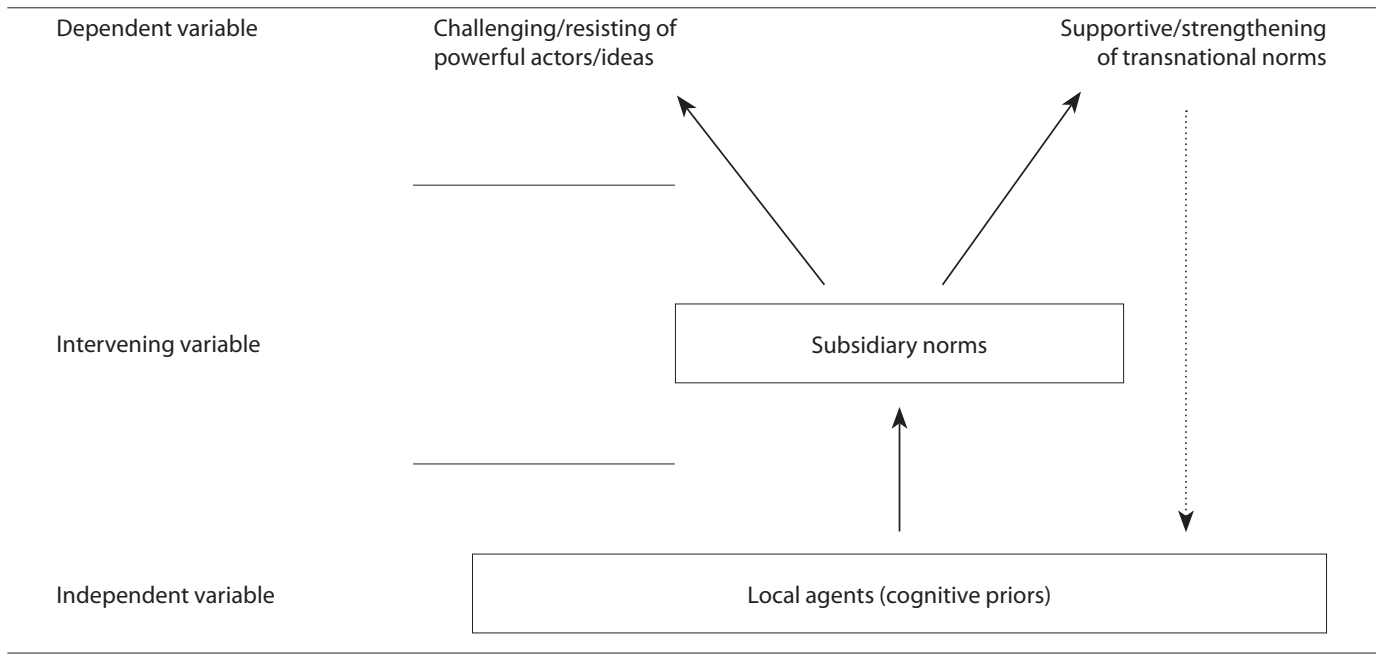

Acharya (2011, p. 99).

22 Localization is "active construction (through discourse, framing, grafting, and cultural selection) of foreign ideas by local actors, which results in the latter developing significant congruence with local beliefs and practices" (Acharya, 2004, p. 245). Norm subsidiarity "concerns the process whereby local actors develop new rules, offer new understandings of global rules or reaffirm global rules in the regional context" (Acharya, 2011, p. 96). 
Said differently, the work that Latin Americans do opens up possibilities for aggregation in International Relations not so much because it is innovative per se, rather because its uniqueness leads other members of the scientific community to reevaluate their theoretical formulations.

\section{DOES A LATIN AMERICAN SCHOOL OF THOUGHT EXIST?}

The Latin American worldview is particular. However, because this worldview is the result of a mix that includes Western elements and because in the scientific realm those elements tend to be more relevant than local ones, its particularity does not translate into a specific "paradigm theory". In International Relations and in Latin America, the obedience to the Dependencia principles demonstrates a struggle to break from the three "paradigm theories" formulated in Europe between the Enlightenment and beginnings of the $20^{\text {th }}$ century. In particular, it reveals a special predicament when it comes to break from the "paradigm-theory" of Marxism. Even if a Latin American Hard Core can be identified (induction, particularism, social structure of domination, social transformation through state action) one cannot definitely exclude any particular analytical process from it.

So, because the Latin American worldview is close to the Western one. Because the ontological/methodological options chosen in Latin America are not different from Western ones. Because the Latin American Hard Core is fundamentally linked to Marx- ism. Because the negative heuristic is neither clearly nor sufficiently defined. Moreover and essentially, because the comparative utility of the Latin American proposals is minimal: it is impossible to conclude that a typically Latin American school of thought in International Relations does exist.

Yet, this cannot constitute a basis on which one could ignore the contributions of our Latin American colleagues to International Relations. If we consider them separately and each one in relation to the scientific project of International Relations, Latin American proposals - essentially conceptual - do participate to the aggregation process. Their usefulness is to be understood in this extrinsic context, not based on their intrinsic value - that, caeteris paribus, is undeniable.

As Walter Mignolo (2011) argues about modernity and science, one could conclude of this short study that there cannot be any truly non-Western thinking unless a process of epistemic decolonization takes place.

Nonetheless, one interesting feature in Latin America is the sociological study of international relations. Even if these kinds of studies are of European inspiration, they do not generate the same debates as those of classical inspiration (realist, liberal, constructivist or critical). Why are works inspired in Kenneth Waltz' or John Ikenberry's theories polemical and those inspired in Weber's, Durkeim's, Badie's or Barbés not? Responding to this question would undoubtedly help us better understand the way Latin American scholars conceive the study of international relations. 


\section{REFERENCES}

Acharya, A. (2004). How Ideas Spread: Whose Norms Matter? Norm Localization and Institutional Change in Asian Regionalism. International Organization, 58 (2), 239-275.

Acharya, A. (2011). Norm Subsidiarity and Regional Orders: Sovereignty, Regionalism, and RuleMaking in the Third World, International Studies Quarterly, 55, 95-123.

Badie B. (2011). La diplomatie de connivence. Les dérives oligarchiques du système international. Paris: Editions La Découverte

Badie, B. (2004). L’impuissance de la puissance : Essai sur les nouvelles relations internationales. Paris: Fayard.

Bello, I. y Peñas Esteban, F. J. (2013). La teoría de Relaciones Internacionales en y desde el Sur. Relaciones Internacionales, 22, 5-7.

Bernal-Meza, R. (2010). Latin American Concepts and Theories and Their Impacts on Foreign Policies. In Sombra Saraiva, F. (ed.). Concepts, Histories and Theories of International Relations for the 21th Century (pp. 131-177). Brasilia: Instituto Brasileiro de Relações Internacionais.

Bethell, L. (2009). O Brasil e a ideia de "América Latina" em perspectiva histórica. Estudos Históricos, 22 (44), 289-321.

Bukharin, N. (1977 [1915]). L'économie mondiale et l'impérialisme: esquisse économique. Paris: Anthropos

Buzan, B. \& Wæver, O. (2003). Regions and Powers. The Structure of International Security. Cambridge: Cambridge University Press

Cardoso, F. E. \& Faletto, E. (1978 [1969]). Dependencia $y$ desarrollo en América Latina: ensayo de interpretación sociológica. México: Siglo xxI Editores.
Cervo, A. L. (2008). Conceitos em Relaçóes Internacionais. Revista Brasileira de Política Internacional, $51(2), 8-25$.

Cervo, A. L. (2013). Conceptos en Relaciones Internacionales. Relaciones Internacionales, 22, 149-166.

Cordero Ulate, A. (2008). El paradigma inconcluso: Kuhn y la sociología en América Latina. Guatemala: FLACSO.

Cox, R. W. (1981). Social Forces, States and World Orders: Beyond International Relations Theory. Millennium-Journal of International Studies, 10 (2), 126-155.

Der Derian, J. (2007). Foulcault et les Autres: rencontres critiques dans le domaine des relations internationales. Revue international des sciences sociales, 1 (191).

Devlen, B., James, P. \& Özdamar, Ö. (2005). The English School, International Relations, and Progress. International Studies Review, 7, 171-197

Dias Duarte, L. F. (2005). La nature nationale : entre l'universalisme scientifique et la particularité symbolique des nations. Civilisations, 52 (2), 21-44. Recuperado de http://civilisations.revues.org/752 Dieter, H. (2009). Changing patterns of regional governance: from security to political economy? Pacific Review, 22 (1), 73-90

Dunne, T. Hansen, L. \& Wight, C. (2013). The End of International Relations Theory. European Journal of International Relations, 19, 405-425.

Escudé, C. (1992). Realismo Periférico. Buenos Aires: Editorial Planeta

Fonseca, G. Jr. (1998). A legitimidade e outras questóes internacionais. São Paulo: Paz e Terra

Frasson-Quenoz, F. (2014). África: ¿una comunidad alienada? In Frasson-Quenoz, F. (ed.). Seguridad Internacional y Ordenamientos regionales: del 
Complejo Regional a la Comunidad de Seguridad (Europa, África, América del Sur y América del Norte) (pp. 93-127). Bogotá: Universidad Externado de Colombia.

Graduate Institute Geneva (2015). Alumni News. Recuperado de http://graduateinstitute.ch/home/ alumni/news.html/_/news/alumni/2015/firstarab-scholar-to-win-global.

Hamati-Ataya, I. (2011). The "Problem of Values" and International Relations Scholarship: From Applied Reflexivity to Reflexivism. International Studies Review, 13 (2), 259-287.

Jackson, P. T. (2014). The "Third Debate" 25 Years Later. Recuperado de http://www.isanet.org/Publications/IsQ/Posts/ID/297/The-Third-Debate25-Years-Later

Jaguaribe, H. et al. (1972). La dominación de América Latina. Buenos Aires: Amorrotu Editores.

James, P. (2002). International Relations and Scientific Progress: Structural Realism Reconsidered. Columbus: Ohio State University Press.

Jervis, R. (1994). Hans Morgenthau, Realism, and the Scientific Study of International Politics. Social Research, 61 (4), 853-876.

Joas, H. \& Knöbl, W. (2009) Social Theory: Twenty Introductory Lectures. Cambridge: Cambridge University Press.

Keohane, R. O. (1988). International Institutions: Two Approaches. International Studies Quarterly, 32 (4), 379-396.

Kuhn, T. (1962). The Structure of Scientific Revolutions. Chicago: University of Chicago Press.

Lakatos, I. (1971). History of Science and Its Rational Reconstructions. In Buck, R.C. \& Cohen, R.S. (eds.). Philosophy of Science Association 1970: In Memory of Rudolf Carnap (pp. 91-136). Dordrecht: D. Reide.
Lapid, Y. (1989). The Third Debate: On the Prospects of International Theory in a Post-Positivist Era. International Studies Quarterly, 33 (3), 235-254.

Lechini, G. (2009). La cooperación Sur-Sur y la búsqueda de autonomía en América Latina: ¿'Mito o realidad? Relaciones Internacionales, 12, 55-81.

Lorenzini, M. E. \& Pereyra Doval, M. G. (2013). Revizando los aportes de las teorías del sur: nexos entre teoría y praxis en Argentina y Brasil. Relaciones Internacionales, 22, 9-26.

Mansfield E. D. \& Milner H. L. (1997). The Political economy of Regionalism. New-York: Columbia University Press.

Mansfield E. D. \& Milner H. L. (1999). The new wave of regionalism. International Organization, 53 (3), 589-627.

Mercadante, A. (2013). Brasil de Lula a Dilma (20032013). Buenos Aires: Capital Intelectual.

Mignolo, W. D. (2011). The Darker Side of Western Modernity: Global Futures, Decolonial Options. Durham and London: Duke University Press.

Morgan, P. M. (1997). Regional Security Complexes and Regional Orders. In Lake, D. A. \& Morgan, P. M. (eds.). Regional Orders: Building Security in a New World (pp. 20-44). University Park, PA: Pennsylvania University Press.

Nel, P. \& Stephen, M. (2009). The foreign economic policies of regional powers in developing world. In Flemes, D. (ed.). Regional Leadership in Global system: Ideas, Interests and Strategies of Regional Powers (pp. 71-90). Burlington, vT: Ashgate.

Onuf, N. G. (1989). World of our Making: Rules and Rule in Social Theory and International Relations. London: Routledge.

Ovando Santana, C. \& Aranda Bustamente, G. (2013). La autonomía en la política exterior latinoamericana: evolución y debates actuales. Pap. Polit., 18 (2). 719-742. 
Pastrana, E. \& Vera, D. (2012). Los desafíos de Colombia frente a la proyección de Brasil como potencia regional y jugador global. In Jost, S. (ed.). Colombia: ¿una potencia en desarrollo? Escenarios y desafios para su politica exterior (pp. 613-641). Bogotá: Konrad Adenauer Stiftung.

Popper, K. (1959). The Logic of Scientific Discovery. New-York: International Publishers.

Popper, K. (1969). Conjectures and Refutations: The Growth of Scientific Knowledge. Nueva York: Routledge and Kegan Paul.

Puig, J. C. (1980). Doctrinas internacionales y Autonomía Latinoamericana. Caracas: Instituto de Altos Estudios de América Latina, Universidad Simón Bolívar.

Puig, J. C. (1984). América Latina: politicas exteriores comparadas. Buenos Aires: Grupo Editor Latinoamericano.

Rapoport, M. \& Míguez, M. C. (2015). Desafíos y ejes para una inserción internacional autónoma de Argentina y América del Sur en el escenario mundial. In Briceño Ruiz, J. \& Simonoff, A. (eds.). Integración y cooperación regional en América Latina: Une relectura a partir de la teoría de la autonomia (pp. 143-162). Buenos Aires: Editorial Biblios.

Russell, R. \& Tokatlían, J. G. (2001). De la autonomía antagónica a la autonomía relacional: una mirada teórica desde el cono sur. PostData, 7, 71-92.

Russell, R. \& Tokatlían, JG. (2002). De la autonomía antagónica a la autonomía relacional: una mirada teórica desde el cono sur. Perfiles Latinoamericanos, 21, 159-194

Sebeok, T. A. \& Umiker-Sebeok, J. (1980). "You Know My Method". A Juxtaposition of Charles S. Pierce and Sherlock Holmes. Blumington: Gaslight.

Sihls, E. (1974). "Ideology and Utopia" by Karl Mannheim. Daedalus, 103 (1), 83-89.
Soligen, E. (2008). The genesis, Design and effects of regional institutions: lessons from East Asia and the Middle East. International Studies Review, 52 (3), 261-294.

Tickner, A. \& Blaney, D. (eds.) (2012). Thinking International Relations Differently. London: Routledge.

Tickner, A. \& Wæver, O. (eds.) (2009). International Relations Scholarship Around the World (Worlding beyond the West). London: Routledge.

Tickner, A. (2008). Latin American IR and the Primacy of lo práctico. International Studies Review, 10, $735-748$

Tickner, A. B. \& Blaney, D. L. (2012). No place for theory? Security Studies in Latin America. In Tickner, A. B. y Blaney, D. L. (eds.). Thinking International Relations Differently (pp. 92-114). Londres: Routledge.

Tickner, J. A. (1988). Hans Morgenthau's Principles of Political Realism: A Feminist Reformulation. Millennium-Journal of International Studies. 17 (3), 429-440.

Tomassini, L. (1989). Teoría y Práctica de la Politica Internacional. Santiago: Ediciones Universidad Católica.

Vigevani, T. \& Cepaluni, G. (2007). A política externa de Lula da Silva: a estratégia da autonomía pela diversificação. Contexto Internacional, 29 (2), 273-335.

Vitalis, R. (2015). White world Order, Black Power Politics: The Birth of American International Relations - The United States in the World. Nueva York: Cornell University Press.

Weber, C. (2014). The gentrification of International Theory. Retriever from http://www.isanet.org/ Publications/IsQ/Posts/ID/313/The-Gentrification-of-International-Theory 